УдК 616-002 - 008.953-092

DOI 10.11603/2414-4533.2017.3.8027

(CI. М. КЛІЩ, Р. В. ВЕРБА

ДВНЗ “Тернопільський державний медичний університет імені І. Я. Горбачевського МОЗ України”

\title{
Використання стовбурових клітин із пуповинної крові для корекції порушень ендогенної інтоксикації у щурів із гострим поширеним перитонітом на тлі мерказоліл-індукованого гіпотиреозу
}

\begin{abstract}
Мета роботи: вивчити вплив мезенхімальних стовбурових клітин на показники ендогенної інтоксикації у щурів з гострим поширеним перитонітом на тлі експериментального гіпотиреозу.

Матеріали і методи. У роботі використовували білих щурів лінії Вістар. Гіпотиреоз моделювали уведенням мерказолілу в дозі 25 мг/кг протягом 21-ї доби. Гострий поширений перитоніт моделювали уведенням 0,5 мл 10 \% профільтрованої калової суспензії в черевну порожнину досліджуваних тварин. Стовбурові клітини отримували з пуповинної крові вагітних самок на 21-24 доби вагітності. Оцінку життєздатності отриманих клітин здійснювали з використанням тесту на включення суправітального барвника методом фарбування 0,1 \% розчином трипанового синього. Суспензію отриманих мононуклеарів уводили внутрішньоочеревинно в дозі 0,5 мл (кількість клітин в уведеній дозі $-0,9-1,0 \times 10^{8}$ ) одразу після моделювання гострого поширеного перитоніту. Проведено визначення молекул середньої маси, еритроцитарного та лейкоцитарного індексів інтоксикації, активності катепсину D.

Результати досліджень та їх обговорення. Проведеними дослідженнями встановлено, що наявність гіпотиреозу в експериментальних тварин, яким моделювали гострий поширений каловий перитоніт, супроводжувалась більш вираженим, ніж в еутиреоїдних щурів, зростанням показників ендотоксикозу - середньомолекулярних пептидів, еритроцитарного та лейкоцитарного індексів інтоксикації та гіршою динамікою їх нормалізації. Спостерігались фазові зміни активності катепсину D. Застосування стовбурових клітин пуповинної крові супроводжується суттєвим зменшенням ендогенної інтоксикації у тварин з експериментальним поширеним перитонітом на тлі мерказоліл-індукованого гіпотиреозу.

Дефіцит йодовмісних гормонів щитоподібної залози супроводжується достовірним зростанням показників, що характеризують синдром ендогенної інтоксикації, порівняно з еутиреоїдними тваринами. Це може бути однією із причин розвитку поліорганної недостатності за цих умов. Застосування стовбурових клітин пуповинної крові супроводжується суттєвим зменшенням ендогенної інтоксикації у тварин з експериментальним поширеним перитонітом на тлі мерказоліл-індукованого гіпотиреозу.
\end{abstract}

Ключові слова: поширений перитоніт; гіпотиреоз; ендогенна інтоксикація; корекція; стовбурові клітини; пуповинна кров.

Постановка проблеми і аналіз останніх досліджень та публікацій. На сьогодні летальність при перитоніті, за даними багатьох авторів, становить від 19 до 70 \% [2]. Аналіз світової статистики показав, що внесок антибактерійної терапії в зниження летальності хворих із перитонітом майже за 100 років (із 1900 до 1980 рр.) не перевищує 20 \% [1], при цьому останнім часом все частіше доводиться стикатися з резистентністю мікрофлори до антибактерійних препаратів, особливо при нозокоміальній інфекції [6].

Серед причин, що зумовлюють тяжкий перебіг перитоніту, важливе місце посідає синдром ендогенної інтоксикації (CEI), який є наслідком надходження у біологічні середовища організму значної кількість токсичних продуктів метаболізму, з одного боку, та неможливістю їх біотрансформації 3 іншого [9]. Незважаючи на схожість патогенезу CEI, при кожній нозологічній формі він має певні специфічні ознаки. Перитоніт умовно можна назвати класичною моделлю CEI, тому його доцільно розглянути як базову модель цього стану [2].

Гіпотиреоз посідає одне з провідних місць у структурі ендокринної патології. Поширеність субклінічного гіпотиреозу в популяції досягає 1012 \%, маніфестного - варіює від 0,2 до 2,0 \%. Знижена продукція тиреоїдних гормонів впливає на функцію і стан багатьох органів і систем, зокрема імунної та антиоксидантної, що суттєво відображається на перебізі патологічних процесів за цих умов [10].

Одним $з$ компонентів сучасного комплексного лікування перитоніту, який не входить до стандартів лікування, є імунокорекція. Сьогодні для імунотерапії використовують препарати, до складу яких входить комплекс імуноглобулінів основних класів (IgAMG). Але роботи на цю тему свідчать, що ці препарати необхідно застосовувати 3 патогенетичної точки зору, своєчасно, у фазі перших проявів симптомів перитоніту і ураження органів, а їх пізніше застосування як “терапія відчаю” є патогенетично і економічно необгрунтованим і неефективним заходом [3].

Останнім часом в зарубіжній періодичній літературі з'явилися роботи, які відкривають нові можливості клітинних технологій, а саме властивості мультипотентних мезенхімальних стовбурових клітин (MCK). Зокрема, стало відомо, що вони здатні 
зменшувати системне запалення, знижувати органну дисфункцію, мають імуномодулюючі властивості; виявлено прямий клітинний вплив з імунними клітинами; вони можуть прямо чи опосередковано моделювати здатність фагоцитів реципієнта знижувати бактерійне навантаження організму [1, $16,19,20]$. Слід зазначити, що в науковій літератуpi результати експериментальних досліджень щодо застосування клітинних технологій при перитоніті представлені недостатньо широко.

Мета роботи: вивчити вплив мезенхімальних стовбурових клітин на показники ендогенної інтоксикації у щурів із гострим поширеним перитонітом на тлі експериментального гіпотиреозу.

Матеріали і методи. В дослідженні використовували білих щурів-самців лінії Вістар, яких утримували на стандартному раціоні віварію при вільному доступі до води відповідно до вимог “Правил проведення робіт з використанням експериментальних тварин” [7]. В кожну експериментальну групу методом випадкової вибірки було включено по 12 тварин масою (230 \pm 20$)$ г, однак внаслідок загибелі у процесі експерименту їх кількість в групах на момент евтаназії була різна.

Гіпотиреоз (ГТ) моделювали щоденним введенням per os за допомогою зонда фармакопейного тиреостатика мерказолілу (“Здоров’я”, Україна) у дозі 25 мг/кг протягом 21 доби [12, 18]. Повноту досягнення гіпотиреозу контролювали вимірюванням концентрації трийодтироніну і тироксину в сироватці крові, а також за динамікою маси тварин та їх рухової активності.

Вплив гіпотиреозу на перебіг гострого поширеного перитоніту (ГПП) вивчали на моделі, запропонованій В. А. Лазаренком і співавт., 2008 [8]. Модель полягає в уведенні 0,5 мл 10 \% профільтрованої калової суспензії в черевну порожнину досліджуваних щурів. Суспензію отримували шляхом змішування ізотонічного розчину і калу зі сліпої кишки двох-трьох інтактних тварин, потім її двічі фільтрували через подвійний шар марлі і через 20 хв після приготування вводили інтактним тваринам пункційним способом. Щоб уникнути пошкодження внутрішніх органів, тварин тримали вертикально, каудальним кінцем вгору. Методом пункції вентральної стінки в центрі середньої лінії живота, направляючи кінець голки по черзі у праве і ліве підребер’я, праву і ліву клубові ділянки, вводили однакову кількість калової суспензії.

Експериментальних тварин розділили на 5 груп:

I - інтактні тварини, яким перорально вводили дистильовану воду протягом 21-ї доби;
II - тварини, яким моделювали гіпотиреоз шляхом перорального уведення мерказолілу в дозі 25 мг/кг протягом 21-ї доби;

III - тварини, яким моделювали гострий каловий перитоніт;

IV - тварини, яким моделювали гострий каловий перитоніт на тлі попередньо змодельованого гіпотиреозу;

$\mathrm{V}$ - тварини $з$ перитонітом, яким уводили стовбурові клітини, отримані з пуповинної крові.

Отримання стовбурових клітин 3 пуповинної крові тварин проводили у вагітних самок, орієнтовно на 21-24 доби вагітності. Під тіопенталовим наркозом в асептичних умовах після обробки операційного поля проводили лапаротомію, виділення плодів. Біля плодового кінця проводили пункцію судин пуповини голкою зі шприцом, змочений у 6 \% розчин етилендіамінтетраоцтової кислоти (ЕДТА). Від однієї вагітної самки отримували 0,5-1,0 мл пуповинної крові з вмістом 6 \% розчину ЕДТА у співвідношенні не менше 10:1. Для трансплантації у черевну порожнину щурів з перитонітом готували суспензію ядерних клітин 3 дотриманням стерильності. 3 цією метою для осадження еритроцитів змішували пуповинну кров з 33 \% розчином поліглюкіну в співвідношенні 1:2. Седиментація тривала протягом 60-90 хв до чіткої межі. Супернатант видаляли, клітини, що залишилися, промивали в фосфатно-сольовому буфері шляхом центрифугування протягом десяти хвилин при 1500 об/хв. Надосад видаляли, клітини ресуспендували шляхом піпеткування. Таким чином отримували суспензію ядерних клітин з їх вмістом 1,8-2×105 в 1 мкл. Для оцінки життєздатності отриманих клітин проводили тест на включення суправітального барвника методом фарбування 0,1 \% розчином трипанового синього [13]. При виділенні фракції ядерних клітин методом седиментації еритроцитів у поліглюкіні отримано 92 \% життєздатних клітин, що підтверджено методом суправітального фарбування. Суспензію отриманих мононуклеарів уводили внутрішньоочеревинно в дозі 0,5 мл (кількість клітин в дозі препарату 0,9-1,0×108) одразу після моделювання гострого поширеного перитоніту.

Тварин декапітували під тіопенталовим наркозом через 24 год, на 4-ту і 7-му і 10-ту доби від початку моделювання перитоніту. Для проведення біохімічних досліджень використовували цільну кров, сироватку крові та гомогенат печінки.

Вміст загального тироксину $\left(\mathrm{T}_{4}\right)$ і загального трийодтироніну $\left(\mathrm{T}_{3}\right)$ у сироватці визначали імунофлуоресцентним методом 3 використанням стандартних тест-наборів “Immulite 1000”. Концентрацію гормонів виражали в пмоль/л. 
Ступінь виразності ендотоксемії оцінювали за вмістом молекул середньої маси (МСM) у сироватці крові, де $\mathrm{MCM}_{1}$ - це вміст молекул середньої маси, визначений при довжині хвилі 254 нм, а MCM $_{2}$ - при довжині хвилі 280 нм, а також ступенем пошкодження еритроцитарної мембрани розраховували еритроцитарний індекс інтоксикації (EII) [15]. Визначення лейкоцитарного індексу інтоксикації проводили згідно з формулою, запропонованою Я. Я. Кальф-Каліфом у модифікації Б. А. Рейса [14].

Для приготування гомогенату тканину печінки розтирали за допомогою гомогенізатора при $4{ }^{\circ} \mathrm{C}$ і суспендували в 9 об’ємах 0,25 М розчину цукрози з 0,001 М ЕДТА, рН 7,4. Сполучнотканинні елементи, які залишились в середовищі, видаляли центрифугуванням (1000 об/хв протягом 3 хв) при охолодженні. Надосадову частина гомогенату печінки використовували для визначення. Активність катепсину D в гомогенаті тканини печінки визначали методом Дингла [4] у модифікації [11] за гідролізом гемоглобіну при $\mathrm{pH} 3,2$. Активність фермента виражали в мкМ тирозину/ (мг білка×год).

Статистичну обробку цифрових даних здійснювали за допомогою програмного забезпечення “Excel” та "STATISTICA”з використанням параметричних і непараметричних методів оцінки отриманих даних. Для всіх показників розраховували значення середньої арифметичної вибірки (M), її дисперсії і помилки середньої (m). Достовірність різниці значень між незалежними кількісними величинами визначали при нормальному розподілі за t-критерієм Стьюдента, в інших випадках - за допомогою U-критерію Мана-Уїтні (достовірним вважали відмінності при $\mathrm{p}<0,05$ ).

Результати досліджень та їх обговорення. 3 метою оцінки функціонального стану щитоподібної залози у тварин, яким моделювали гіпотиреоз, визначали концентрацію тиреоїдних гормонів у крові. Концентрація $\mathrm{T}_{3}$ у здорових щурів склала $(17,70 \pm 0,58)$ пмоль/л, а у тварин, яким вводили мерказоліл, показник був знижений у 2,9 раза і становив $(8,96 \pm 0,26)$ пмоль/л. Концентрація $\mathrm{T}_{4}$ у інтактних щурів склала $(6,30 \pm 0,14)$ пмоль/л, а після уведення мерказолілу зменшилась у 2 рази від показника інтактних щурів і склала $(3,09 \pm 0,08)$ пмоль/л. Ми спостерігали також суб'єктивні ознаки гіпотиреозу - зменшення рухливості, інтенсивніше, ніж у інтактних тварин зростання маси тіла, зміни шерсті. Це вказує на розвиток у тварин явищ гіпотиреозу внаслідок тривалого уведення мерказолілу в дозі 25 мг/кг.
Моделювання гіпотиреозу призвело до зростання ступеня ендотоксемії (табл. 1). Зокрема, вміст МСМ, що визначали при довжині хвилі $\lambda=254$ нм, склав 146,5 \% від рівня контрольних тварин, а при довжині хвилі $\lambda=280-128 \%$. На 21 \% зріс також показник EII, та на 22 \% - ЛII. Достовірне зниження концентрації катепсину D (85 \% від норми), вказує на те, що причиною цього може бути зниження катаболічних процесів за умов дефіциту тиреоїдних гормонів. Це збігається з результатами інших дослідників, які також вказують на суттєве зниження катаболічних процесів за умов дефіциту тиреоїдних гормонів [21].

Моделювання гострого поширеного перитоніту в еутиреоїдних тварин супроводжувалось суттєвим зростання ендотоксемії. Зокрема, вже через 24 год від моменту уведення калової суміші вміст МСМ був достовірно вищим від нормальних значень і склав 196 \% від рівня інтактних тварин. Показник МСМ $_{2}$ склав 222 \% від норми, що вказує на інтенсивніше накопичення ароматичних сполук. Значне зростання зафіксовано і щодо еритроцитарного та лейкоцитарного індексів інтоксикації - ЕІІ склав 157 \%, а ЛІІ - 245 \% від рівня здорових тварин. Суттєве підвищення вмісту катепсину D, яке можна пояснити більш масивною міграцією нейтрофілів у вогнище ураження, вказує на інші причини зростання ендотоксемії за цих умов - ймовірно зниження елімінації деградованих молекул внаслідок порушення кровотоку та фільтраційної здатності нирок.

На 4-ту добу після моделювання ГПП ступінь ендогенної інтоксикації був ще вищим. Зокрема, вміст середньо молекулярних пептидів зріс, відповідно, у 2,4 та 2,6 раза, ЕІІ - в 1,3, а ЛII - у 2,9 раза. Водночас зменшувався вміст катепсину D порівняно з попереднім терміном спостереження. В подальшому у тварин, які вижили, показники дещо покращувались, однак на 10-ту добу спостереження вміст $\mathrm{MCM}_{1}$ все ж перевищував рівень інтактних тварин в 1,9 раза, MCM $_{2}$ - в 1,8 раза. Значно меншим, порівняно з попередніми термінами спостереження, був ЛІІ - 131 \% від рівня інтактних тварин. Зменшився також вміст катепсину D. Однак показник EII був вищим, ніж на 4-ту i 7-му доби спостереження і склав 145 \% від норми.

У тварин, яким ГПП моделювали на тлі гіпотиреозу, ступінь ендотоксемії був значно вищим, ніж в еутиреоїдних тварин, яким моделювали ГПП. Зокрема, вже через 24 год від моменту уведення калової суміші вміст MCM $_{1}$ зріс у 2,4 раза відносно інтактних тварин та був на 23 \% вищим від еутиреоїдних щурів з ГПП. Ще більше зростання мало місце стосовно $\mathrm{MCM}_{2}$ - відповідно, у 2,7 раза від- 
Таблиця 1. Показники ендогенної інтоксикації у щурів з гострим перитонітом на тлі гіпотиреозу та

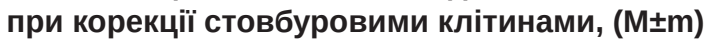

\begin{tabular}{|c|c|c|c|c|c|c|}
\hline \multicolumn{2}{|c|}{ Показник/група тварин } & $\begin{array}{c}\text { MCM }_{1} \text {, } \\
\text { ум. од. екст. }\end{array}$ & $\begin{array}{l}\mathrm{MCM}_{2}, \text { ум. } \\
\text { од. екст. }\end{array}$ & EII, \% & ЛІІ, \% & $\begin{array}{c}\text { Катепсин D, мкM/ } \\
\text { (мг білка × год) }\end{array}$ \\
\hline \multicolumn{2}{|c|}{ Інтактні, n=12 } & $\begin{array}{c}0,344 \pm \\
0,013\end{array}$ & $\begin{array}{c}0,214 \pm \\
0,005\end{array}$ & $\begin{array}{c}29,57 \pm \\
0,71\end{array}$ & $\begin{array}{c}1,02 \pm \\
0,02\end{array}$ & $\begin{array}{c}0,209 \pm \\
0,008\end{array}$ \\
\hline \multicolumn{2}{|c|}{ Гіпотиреоз, n=12 } & $\begin{array}{l}0,504 \pm \\
0,012^{*}\end{array}$ & $\begin{array}{l}0,274 \pm \\
0,008^{*}\end{array}$ & $\begin{array}{c}35,85 \pm \\
0,94^{*}\end{array}$ & $\begin{array}{l}1,24 \pm \\
0,03^{*}\end{array}$ & $\begin{array}{l}0,177 \pm \\
0,007^{*}\end{array}$ \\
\hline \multirow[t]{4}{*}{$\begin{array}{c}\text { Гострий } \\
\text { перитоніт }\end{array}$} & $\begin{array}{l}24 \text { год, } \\
n=10\end{array}$ & $\begin{array}{l}0,673 \pm \\
0,009 *\end{array}$ & $\begin{array}{l}0,475 \pm \\
0,010^{*}\end{array}$ & $\begin{array}{c}46,41 \pm \\
0,39 *\end{array}$ & $\begin{array}{l}2,50 \pm \\
0,04^{*}\end{array}$ & $\begin{array}{l}0,372 \pm \\
0,009 *\end{array}$ \\
\hline & $\begin{array}{l}\text { 4-а доба, } \\
n=9\end{array}$ & $\begin{array}{l}0,822 \pm \\
0,008 *\end{array}$ & $\begin{array}{l}0,564 \pm \\
0,017^{*}\end{array}$ & $\begin{array}{c}37,98 \pm \\
0,88 *\end{array}$ & $\begin{array}{l}3,03 \pm \\
0,05^{*}\end{array}$ & $\begin{array}{l}0,363 \pm \\
0,008 *\end{array}$ \\
\hline & $\begin{array}{l}\text { 7-а доба, } \\
\mathrm{n}=7\end{array}$ & $\begin{array}{l}0,599 \pm \\
0,005^{*}\end{array}$ & $\begin{array}{l}0,347 \pm \\
0,011^{*}\end{array}$ & $\begin{array}{c}35,33 \pm \\
0,78^{*}\end{array}$ & $\begin{array}{l}2,82 \pm \\
0,03^{*}\end{array}$ & $\begin{array}{l}0,318 \pm \\
0,007 *\end{array}$ \\
\hline & $\begin{array}{l}\text { 10-а доба, } \\
n=6\end{array}$ & $\begin{array}{l}0,654 \pm \\
0,011^{*}\end{array}$ & $\begin{array}{l}0,393 \pm \\
0,011^{*}\end{array}$ & $\begin{array}{c}42,97 \pm \\
1,40^{*}\end{array}$ & $\begin{array}{l}1,34 \pm \\
0,06 *\end{array}$ & $\begin{array}{l}0,293 \pm \\
0,008 *\end{array}$ \\
\hline \multirow{4}{*}{$\begin{array}{c}\text { ГТ+ } \\
\text { гострий } \\
\text { перитоніт }\end{array}$} & $\begin{array}{l}24 \text { год, } \\
n=12\end{array}$ & $\begin{array}{l}0,828 \pm \\
0,007^{* \#}\end{array}$ & $\begin{array}{l}0,568 \pm \\
0,008 * \#\end{array}$ & $\begin{array}{l}52,93 \pm \\
0,93 * \#\end{array}$ & $\begin{array}{l}2,87 \pm \\
0,03^{* \#}\end{array}$ & $\begin{array}{l}0,287 \pm \\
0,005^{* \#}\end{array}$ \\
\hline & $\begin{array}{l}\text { 4-a доба, } \\
n=8\end{array}$ & $\begin{array}{l}0,893 \pm \\
0,012 * \#\end{array}$ & $\begin{array}{l}0,663 \pm \\
0,004^{* \#}\end{array}$ & $\begin{array}{l}53,31 \pm \\
1,13^{* \#}\end{array}$ & $\begin{array}{l}3,38 \pm \\
0,05^{* \#}\end{array}$ & $\begin{array}{c}0,276 \pm \\
0,006^{* \#}\end{array}$ \\
\hline & $\begin{array}{l}\text { 7-а доба, } \\
n=6\end{array}$ & $\begin{array}{l}0,820 \pm \\
0,009 * \#\end{array}$ & $\begin{array}{l}0,488 \pm \\
0,012 * \#\end{array}$ & $\begin{array}{l}42,98 \pm \\
1,34^{* \#}\end{array}$ & $\begin{array}{l}3,33 \pm \\
0,07 * \#\end{array}$ & $\begin{array}{l}0,272 \pm \\
0,005^{* \#}\end{array}$ \\
\hline & $\begin{array}{l}\text { 10-а доба, } \\
n=5\end{array}$ & $\begin{array}{l}0,807 \pm \\
0,007^{* \#}\end{array}$ & $\begin{array}{l}0,489 \pm \\
0,006^{* \#}\end{array}$ & $\begin{array}{l}48,34 \pm \\
1,76^{* \#}\end{array}$ & $\begin{array}{l}2,72 \pm \\
0,09 * \#\end{array}$ & $\begin{array}{l}0,264 \pm \\
0,007^{* \#}\end{array}$ \\
\hline \multirow{4}{*}{$\begin{array}{c}\text { ГТ+ } \\
\text { гострий } \\
\text { перитоніт } \\
+ \\
\text { корекція }\end{array}$} & $\begin{array}{l}24 \text { год, } \\
\mathrm{n}=12\end{array}$ & $\begin{array}{c}0,616 \pm \\
0,006^{* \wedge}\end{array}$ & $\begin{array}{c}0,340 \pm \\
0,009 * \wedge\end{array}$ & $\begin{array}{c}45,61 \pm \\
0,76^{\wedge}\end{array}$ & $\begin{array}{c}2,08 \pm \\
0,04 * \wedge\end{array}$ & $\begin{array}{l}0,338 \pm \\
0,006 \wedge\end{array}$ \\
\hline & $\begin{array}{l}\text { 4-а доба, } \\
n=11\end{array}$ & $\begin{array}{l}0,583 \pm \\
0,010 *\end{array}$ & $\begin{array}{c}0,259 \pm \\
0,003^{* \wedge}\end{array}$ & $\begin{array}{l}39,70 \pm \\
0,97 * \wedge\end{array}$ & $\begin{array}{c}2,58 \pm \\
0,04 * \wedge\end{array}$ & $\begin{array}{l}0,326 \pm \\
0,006 \wedge\end{array}$ \\
\hline & $\begin{array}{l}\text { 7-а доба, } \\
\text { n=10 }\end{array}$ & $\begin{array}{c}0,432 \pm \\
0,007 * \wedge\end{array}$ & $\begin{array}{c}0,247 \pm \\
0,007 * \wedge\end{array}$ & $\begin{array}{c}36,87 \pm \\
1,27^{*}\end{array}$ & $\begin{array}{c}2,25 \pm \\
0,03 * \wedge\end{array}$ & $\begin{array}{l}0,322 \pm \\
0,005 \wedge\end{array}$ \\
\hline & $\begin{array}{l}\text { 10-а доба, } \\
n=9\end{array}$ & $\begin{array}{c}0,585 \pm \\
0,010 * \wedge\end{array}$ & $\begin{array}{c}0,347 \pm \\
0,009 * \wedge\end{array}$ & $\begin{array}{l}31,69 \pm \\
1,31 * \wedge\end{array}$ & $\begin{array}{l}1,44 \pm \\
0,03 * \wedge\end{array}$ & $\begin{array}{c}0,314 \pm \\
0,006 * \wedge\end{array}$ \\
\hline
\end{tabular}

Примітки:

1.* - зміни показників еутиреоїдних і гіпотиреоїдних тварин із гострим перитонітом і тварин з корекцією достовірні відносно інтактних.

2. \# - зміни показників гіпотиреоїдних тварин із гострим перитонітом достовірні відносно показників еутиреоїдних на відповідні доби дослідження.

3. ^ - зміни показників тварин з корекцією достовірні відносно гіпотиреоїдних тварин із гострим перитонітом на відповідні доби дослідження.

носно інтактних та 120 \% відносно еутиреоїдних щурів. Показник ЕІІ склав 179 \%, а ЛІІ - 281 \% від норми, при цьому зростання вмісту катепсину D було незначним - 137 \% від норми. До 4-ї доби показники, що характеризують стан ендогенної інтоксикації, продовжували зростати. Зокрема, вміст МСМ склав відповідно 260 і 310 \%, достовірно перевищуючи також аналогічні показники еутиреоїдних тварин з ГПП. Аналогічне зростання зафіксовано і щодо ЕII та ЛІІ - відповідно 180 та 331 \% від норми. Показник катепсину D практично не змінився порівняно з попереднім терміном спостереження, однак був достовірно меншим від аналогічного показника еутиреоїдних тварин.
У подальші терміни спостереження, на відміну від групи еутиреоїдних щурів, де спостерігалась певна стабілізація рівня ендотоксемії, у гіпотиреоїдних тварин показники майже не змінювались, а деякі навіть погіршувались і до 10-ї доби спостереження достовірно відрізнялись як від інтактних тварин, так і тварин з нормальним рівнем тиреоїдних гормонів, яким моделювали ГПП.

Привертає увагу факт, що до 10-ї доби протеазна активність катепсину D знизилась на 9 \% від початку експерименту, тоді як у групі еутиреоїдних тварин ми відмітили суттєве зниження активності катепсину D за аналогічний період - на 40 \%. 
Уведення стовбурових клітин мало позитивний ефект, зменшуючи виразність показників, що характеризують синдром ендогенної інтоксикації. Зокрема, вже через 24 год після уведення тваринам з поширеним перитонітом, що перебігав на тлі гіпотиреозу, вміст МСМ був достовірно меншим, ніж у тварин, яким корекцію не проводили. $\mathrm{MCM}_{1}$ склав 74,4 \% від цієї групи, а MCM $_{2}-60$ \%, однак показники були достовірно вищими, порівняно зі здоровими тваринами. На зменшення ендотоксикозу вказує і зменшення еритроцитарного та лейкоцитарного індексів інтоксикації - відповідно, 86,1 i 72,5 \% від показників групи III. Активність катепсину D зросла і склала 117,8 \% від показника еутиреоїдних тварин з перитонітом. Варто зазначити, що всі показники достовірно відрізнялись від аналогічних параметрів інтактних тварин. До 4-ї доби спостерігали подальше зниження маркерів ендогенної інтоксикації. Зокрема, МСМ склав 65,3 \% від аналогічного показника тварин, яким корекцію не проводили, MCM $_{2}-39,1 \%$, EII - 74,5 \%, ЛІІ 76,3 \%. Достовірно зросла також активність катепсину D, склавши 118,1 \% від рівня тварин групи IV . На 7-му добу дослідження спостерігалась тенденція, подібна до попереднього терміну спостереження. Концентрація $\mathrm{MCM}_{1}$ i надалі знижувалась і порівняно з аналогічним показником групи IV склала $52,7 \%$, а $\mathrm{MCM}_{2}-50,1 \%$. Достовірно зменшувались також еритроцитарний і лейкоцитарний індекси інтоксикації, склавши, відповідно, 85,8 та 67,6 \% від аналогічних показників групи IV. Показник катепсину D залишався майже на рівні 4-ї доби і на 18,4 \% перевищував рівень тварин без корекції. До завершення терміну спостереження (10-та доба) концентрація молекул середньої маси дещо зросла порівняно з 7-ю добою, однак була достовірно меншою від аналогічних показників тварин групи IV (відповідно, 72,5 і 70,9 \% від їх рівня). Еритроцитарний індекс інтоксикації зменшився до рівня інтактних тварин, а ЛІІ хоч і зменшився майже у 2 рази, порівняно з попереднім терміном спостереження, все ж склав 141 \% від рівня інтактних тварин. Активність катепсину D порівняно з попереднім терміном спостереження змінилась несуттєво і була достовірно вищою від аналогічного показни-

\section{СПИСОК ЛІТЕРАТУРИ}

1. Аверьянов А. В. Эффекты комбинированного лечения аллогенными мезенхимальными стволовыми клетками костного мозга и эритропоэтином в экспериментальной модели сепсиса / А. В. Аверьянов, А. Г. Коноплянников // Инфекции в хирургии. - 2012. - № 4. С. 43-48.

2. Бойко В. В. Распространенный гнойный перитонит / В. В. Бойко, И. Л. Криворучко, С. И. Тесленко. - Х. : Прапор, 2008. -278 с. ка групи IV, що вказує на зростання активності катаболічних процесів.

Отже, застосування стовбурових клітин із пуповинної крові має позитивний вплив на показники ендогенної інтоксикації. Це підтверджують й інші дослідники. Зокрема, Хu J. та ін. вказують, що мезенхімальні стовбурові клітини, які ввели мишам разом з бактерійним ліпополісахаридом, запобігають не тільки розвитку гострого пошкодження легень, а й зменшують системну запальну відповідь, достовірно знижуючи сироваткові рівні прозапальних цитокінів IFN- $\gamma$, IL-1 $\beta$, IL-6, MIP$1 \alpha$ i IL- 8 [23]. Інше експериментальне дослідження, яке довело ефективність МСК в моделі сепсису у мишей, викликаного перев’язкою і пункцією товстої кишки, було виконано Меі S.Н. та співавт. [20]. У цій роботі встановлено не тільки зниження рівня маркерів системного запалення під впливом MCK, а й зменшення бактерійного обсіменіння селезінки і ознак поліорганної недостатності. У ще одному дослідженні на моделі сепсису у щурів доведено зниження функціональної депресії міокарда і пригнічення тканинної експресії ІЛ-1 $\beta$ і ІЛ-6 у тварин, які отримали лікування МСК [22].

Важливою властивістю МСК, яка пояснює їх ефективність при інфекційних процесах, є самостійна продукція антимікробного пептиду - кателіцидину hCAP-18/LL-37, що пригнічує переважно розмноження грамнегативних мікроорганізмів. Оскільки при інгібуванні цього білка антимікробна активність МСК знижувалася майже в 2 рази, автори зробили висновок, що прямий антибактеріальний ефект МСК при легеневій інфекції можна порівняти за значимістю з пластичністю і паракринною активністю [19].

Висновки. 1. Дефіцит йодовмісних гормонів щитоподібної залози спричиняє достовірне зростання ендотоксемії, порівняно з еутироїдними тваринами.

2. Застосування стовбурових клітин пуповинної крові супроводжується суттєвим зменшенням ендогенної інтоксикації у тварин з експериментальним поширеним перитонітом на тлі мерказоліл-індукованого гіпотиреозу.

3. Брискин Б. С. Иммунные нарушения и иммунокоррекция при интраабдоминальной инфекции / Б. С. Брискин, Н. Н. Хачатрян, 3. И. Савченко // Хирургия. - 2004. - № 2. - С. 24-27.

4. Дингл Дж. Методы исследования / Дингл Дж. - М. : Мир, 1980. - 344 с.

5. Дзюбановський І. Я. Синдром поліорганної недостатності та його корекція у хворих на гострий поширений перито- 
ніт / І. Я. Дзюбановський, Б. О. Мігенько // Український журнал хірургії. - 2009. - № 2. - С. 56-59.

6. Костюченко А. Л. Интенсивная терапия послеоперационной раневой инфекции и сепсиса / А. Л. Костюченко, А. Н. Бельских, А. Н. Тулупов. - СПб. : Фолиант, 2000. 448 c.

7. Кожем'якін Ю. М. Науково-практичні рекомендації 3 утримання лабораторних тварин та роботи з ними / Ю. М. Кожем'якін, О. С. Хромов, М. А. Філоненко. - К. : Авіцена, 2002. - 156 с.

8. Лазаренко В. А. Экспериментальная модель распространенного калового перитонита / В. А. Лазаренко, В. А. Липатов, Ю. Ю. Блинков // Человек и его здоровье. - 2008. - № 4. - C. $128-132$.

9. Остапенко В. А. К патогенезу синдрома эндогенной интоксикации. В кн. : Эндогенные интоксикации. - СПб. : 1994.

- C. 43.

10. Паньків В. І. Практична тиреоїдологія : монографія / В. І. Паньків. - Донецьк : Заславський О. Ю., 2011. - 224 с.

11. Подунай Ю. А. Возрастная динамика активности катепсинов и содержания среднемолекулярных пептидов в мышцах морского ерша / Ю. А. Подунай, И. Н. Залевская, И. И. Руднева // Ученые записки Таврического национального университета им. В. И. Вернадского. Серия “Биология, химия”. - 2009. - Т. 22 (61), - № 4. - С. 128-134.

12. Ром-Бугославська О. С. Доклінічне вивчення тиреостатичних та тиреоїд-стимулюючих засобів / О. С. РомБугославська, Т. С. Божко, І. В. Комарова // Доклінічні дослідження лікарських засобів: Метод. рекомендації.- Київ, 2001. - C. 409-420.

13. Самохина Л. М. Сочетанное влияние ритмического холодового воздействия и кордовой крови на активность протеиназ и их ингибиторов у старых крыс со стимулированной гипертензией / Л. М. Самохина, В. Г. Бабийчук, В. В. Ломако // Проблемы криобиологии. - 2001. - № 3. - С. 82-83.

14. Сперанский И. И. Общий анализ крови - все ли его возможности исчерпаны? Интегральные индексы интоксикации как критерии оценки тяжести течения эндогенной интоксика-

\section{REFERENCES}

1. Averyanov, A.V., \& Konoplyannikov, A.H. (2012). Effekty kombinirovannogo lecheniya allogennymi mezenkhimalnymi stvolovymi kletkami kostnogo mozga i eritropoetinom $\mathrm{v}$ eksperimentalnoy modeli sepsisa [Effects of combined treatment with allogeneic mesenchymal bone marrow stem cells and erythropoietin in the experimental sepsis model]. Infektsii $v$ khirurgii - Infections in Surgery, 4, 43-48 [in Russian].

2. Boyko, V.V., Kryvoruchko, I.L., Teslenko, S.I., \& Syvozhelezov, A.V. (2008). Rasprostranennyy gnoynyy peritonit [Common purulent peritonitis]. Kharkov: Prapor [in Russian].

3. Bryskin, B.S., Khachatryan, N.N., \& Savchenko, Z.I. (2004). Immunnyye narusheniya i immunokorrektsiya pri intraabdominalnoy infektsii [Immune disorders and immunocorrection with intra-abdominal infection]. KhirurgiyaSurgery, 2, 24-27 [in Russian].

4. Dingl Dzh. (1980). Metody issledovaniya [Methods of research]. Moscow: Mir [in Russian].

5. Dziubanovskyi, I.Ya., \& Mihenko, B.O. (2009). Syndrom poliorhannoi nedostatnosti ta yoho korektsiia u khvorykh na hostryi poshyrenyi perytonit [Organ failure syndrome and its correction in patients with acute peritonitis]. Ukrainskyi zhurnal khirurhii - Ukrainian Journal of Surgery, 2, 56-59 [in Ukrainian]. 6. Kostyuchenko, A.L., Belskikh, A.N., \& Tulupov, A.N. (2000). Intensivnaya terapiya posleoperatsionnoy ranevoy infektsii i ции, ее осложнений и эффективности проводимого лечения / И. И. Сперанский, Г. Е. Самойленко, М. В. Лобачева // Здоровье Украины. - 2009. - № 6 (19). - С. 51-57.

15. Тогайбаев А. А. Метод определения эндогенной интоксикации / А. А. Тогайбаев, А. В. Кургузкин, И. В. Рикун // Лаб. дело. - 1988. - № 9. - С. 22-24.

16. Garcia-Gomez I. Mesenchymal stem cells: biological properties and clinical applications / I. Garcia-Gomez, G. Elvira, A.G. Zapata // Expert. Opin. Biol. Ther. - 2010 . - No. 10. P.1453-1468.

17. Hosoon C. Anti-inflammatory protein TSG-6 secreted by activated MSCs attenuates zymosan-induced mouse peritonitis by decreasing TLR2/NF-B signaling in resident macrophages / C. Hosoon, L. RyangHwa, N. Bazhanov // Blood. - 2011. Vol. 118, No. 3. - P. 330-338.

18. Isman C. A. Methimazole-induced hypothyroidism in rats ameliorates oxidative injury in experimental colitis / C. A. Isman, B. C. Yegen, I. Alican // J. Endocrinol. - 2003. - Vol. 177, No. 3. - P. 471-476.

19. Krasnodembskaya A. Antibacterial effect of human mesenchymal stem cells is mediated in part from secretion of the antimicrobial peptide LL-37 / A. Krasnodembskaya, Y. Song, X. Fang // Stem Cells. - 2010. - № 28. - P. 229-238.

20. Mei S. H. Mesenchymal stem cells reduce inflammation while enhancing bacterial clearance and improving survival in sepsis / S. H. Mei, J. J. Haitsma, C. C. Dos Santos // J. Respir.Crit. Care. Med. - 2010. - Vol. 182, No. 8. - P. 1047-1057.

21. Wiederanders B. Accumulation of inactive cathepsin D in old rats / B. Wiederanders, B. Oelke. // Mech. Ageing Dev. - 1982. Vol. 24, No. 3. - P. 265-271.

22. Mesenchymal stem cells attenuate myocardial functional depression and reduce systemic and myocardial inflammation during endotoxemia / B. R. Weil, M. C. Manukyan, J. L. Herrmann [et al.] // Surgery. - 2010. - Vol. 148, No. 2. - P. 444-452.

23. $\mathrm{Xu}$ J. Prevention of endotoxin-induced systemic response by bone marrow-derived mesenchymal stem cells in mice / J. Xu, C.R. Woods, A. L. Mora // Am. J. Physiol. Lung. Cell. Mol. Physiol. - 2007. - Vol. 29, No. 3. - P.131-141.

sepsisa [Intensive therapy of postoperative wound infection and sepsis]. Saint-Petersburg: Foliant [in Russian].

7. Kozhemiakin, Yu.M., Khromov, O.S., Filonenko, M.A., \& Saifetdinova, H.A. (2002). Naukovo-praktychni rekomendatsii z utrymannia laboratornykh tvaryn ta roboty z nymy [Scientific and practical advice on keeping laboratory animals and work with them]. Kyiv: Avitsena [in Ukrainian].

8. Lazarenko, V.A., Lipatov, V.A., Blinkov, Yu.Yu., \& Skorikov, D.V. (2008). Eksperimentalnaya model rasprostranennogo kalovogo peritonita [Experimental model of widespread fecal peritonitis]. Chelovek i yego zdorovye - Man and His Health, 4, 128-132 [in Russian].

9. Ostapenko, V.A. (1994). K patogenezu sindroma endogennoy intoksikatsii. V kn. Endogennye intoksikatsii [To the pathogenesis of the syndrome of endogenous intoxication. In a book Endogenous Intoxications]. Saint-Petersburg [in Russian].

10. Pankiv, V.I. (2012). Praktychna tyreoidolohiia: monohrafiia [Practical thyroidology: monography]. Donetsk: Zaslavskiy O.Yu. [in Ukrainian].

11. Podunay, Yu.A., Zalevskaya, I.N., \& Rudneva, I.I. (2009). Vozrastnaya dinamika aktivnosti katepsinov i soderzhaniya srednemolekulyarnykh peptidov $\mathrm{v}$ myshtsakh morskogo yersha [Age dynamics of cathepsin activity and content of mediummolecular peptides in sea-buckthorn muscles]. Uchenyye zapiski 
Tavricheskogo natsionalnogo universiteta im. V.I. Vernadskogo. Seriya "Biologiya, khimiya" - Scientific notes of the Taurida National University named after V.I. Vernadskyy. Series "Biology, Chemistry”, 4 (61), 128-134 [in Russian].

12. Rom-Buhoslavska, O.S., Bozhko, T.S., \& Komarova, I.V. (2001). Doklinichne vyvchennia tyreostatychnykh ta tyreoidstymuliuiuchykh zasobiv [Pre-clinical study and thyreostatic tyreoyid-stimulants drugs]. Doklinichni doslidzhennia likarsykykh zasobiv: Metod. rekomendatsii - Preclinical Studies of Drugs: Guidelines, Kyiv, 409-420 [in Ukrainian].

13. Samokhina, L.M., Babiychuk, V.G., \& Lomako, V.V. (2001). Sochetannoye vliyaniye ritmicheskogo kholodovogo vozdeystviya i kordovoy krovi na aktivnost proteinaz i ikh ingibitorov u starykh krys so stimulirovannoy gipertenziyey [Combined effect of rhythmic cold exposure and cord blood on the activity of proteinases and their inhibitors in old rats with stimulated hypertension]. Problemy kriobiologii - Problems of Cryobiology, 3, 82-83 [in Russian].

14. Speranskiy, I.I., Samoylenko, G.Ye., \& Lobacheva, M.V. (2009). Obshchiy analiz krovi - vse li yego vozmozhnosti ischerpany? Integralnyye indeksy intoksikatsii kak kriterii otsenki tyazhesti techeniya endogennoy intoksikatsii, yeye oslozhneniy i effektivnosti provodimogo lecheniya [The general or common analysis of a blood - whether all its possibilities are settled or exhausted? Integral indices of intoxication as criteria for assessing the severity of the course of endogenous intoxication, its complications and the effectiveness of the ongoing treatment]. Zdorovye Ukrainy - Health of Ukraine, 6 (19), 51-57 [in Russian]. 15. Togaybayev, A.A., Kurguzkin, A.V., \& Rikun, I.V. (1988). Metod opredeleniya endogennoy intoksikatsii [Method for the determination of endogenous intoxication]. Laboratornoye delo
- Laboratory Work, 9, 22-24. [in Russian].

16. Garcia-Gomez, I., Elvira, G. \& Zapata, A.G. (2010). Mesenchymal stem cells: biological properties and clinical applications. Expert. Opin. Biol. Ther., (10), 1453-1468.

17. Hosoon, C., RyangHwa, L., \& Bazhanov, N. (2011). Antiinflammatory protein TSG-6 secreted by activated MSCs attenuates zymosan-induced mouse peritonitis by decreasing TLR2/NF-B signaling in resident macrophages. Blood, 118 (3), 330-338.

18. Isman, C.A., Yegen, B.C., \& Alican, I. (2003) Methimazoleinduced hypothyroidism in rats ameliorates oxidative injury in experimental colitis. J. Endocrinol., 177 (3), 471-476.

19. Krasnodembskaya, A., Song, Y., \& Fang X. (2010). Antibacterial effect of human mesenchymal stem cells is mediated in part from secretion of the antimicrobial peptide LL-37. Stem Cells, 28, 229-238.

20. Mei, S.H., Haitsma, J.J., \& Dos Santos C.C. (2010). Mesenchymal stem cells reduce inflammation while enhancing bacterial clearance and improving survival in sepsis. Am. Respir. Crit. Care. Med., 182 (8), 1047-1057.

21. Wiederanders, B, \& Oelke, B. (1982). Accumulation of inactive cathepsin D in old rats. Mech. Ageing Dev., 24 (3), 265271.

22. Weil, B.R., Manukyan, M.C., \& Herrmann, J.L. (2010). Mesenchymal stem cells attenuate myocardial functional depression and reduce systemic and myocardial inflammation during endotoxemia. Surgery, 148 (2), 444-452.

23. Xu, J., Woods, C.R., \& Mora, A.L. (2007). Prevention of endotoxin-induced systemic response by bone marrow-derived mesenchymal stem cells in mice. Am. J. Physiol. Lung. Cell. Mol. Physiol., 293 (3), 131-141.

\title{
USE OF CORD BLOOD STEM CELLS FOR CORRECTION OF VIOLATIONS OF ENDOGENOUS INTOXI- CATION IN RATS WITH ACUTE DISTRIBUTED PERITONITIS ON THE BACKGROUND OF MERCAZO- LIL-INDUCED HYPOTHYROTHESIS
}

\begin{abstract}
The aim of the work: to study the influence of mesenchymal stem cells on the indices of endogenous intoxication in rats with acute widespread peritonitis on the background of experimental hypothyroidism.

Materials and Methods. White Wistar rats were used in the work. Hypothyroidism was modeled by the administration of Mercazolil at a dose of $25 \mathrm{mg} / \mathrm{kg}$ for 21 days. Acute common peritonitis was modeled by injecting $0.5 \mathrm{ml}$ of $10 \%$ filtered fecal suspension into the abdominal cavity of the animals under study. Stem cells were obtained from umbilical cord blood of pregnant females on the 21-24th day of pregnancy. Evaluation of the viability of the obtained cells was carried out using the test for inclusion of the supra-red dye by staining with $0.1 \%$ trypan blue. The suspension obtained mononuclear cells were injected intraperitoneally in a dose of $0.5 \mathrm{ml}$ (number of cells administered dose $-0.9-1.0 \times 108$ ) immediately after the simulation common acute peritonitis. determination of the average molecular weight was conducted, leukocyte and erythrocyte indices intoxication activity of cathepsin D.

Results and Discussion. The research found that the presence of hypothyroidism in experimental animals, which simulated an acute common fecal peritonitis, accompanied by a more pronounced than in euthyroid rats, an increase of endotoxemia indicators - middle molecules, erythrocyte and leukocyte index of intoxication, and slow dynamics of their normalization. Phase changes observed activity of cathepsin D. The use of cord blood stem cells is accompanied by a significant decrease in endogenous toxicity in animals with experimental peritonitis common amid Mercazolilum-induced hypothyroidism.

Deficiency of iodine-containing thyroid hormones accompanied by a significant increase in the indicators characterizing the syndrome of endogenous intoxication compared to eutireoid animals. This may be one of the reasons for the development of multiple organ failure in these conditions. The use of stem cell cord blood is accompanied by a significant decrease in endogenous intoxication in experimental animals with generalized peritonitis in the background of mercazolil-induced hypothyroidism.
\end{abstract}

Key words: common peritonitis; hypothyroidism; endogenous intoxication; correction; stem cells; cord blood. 


\author{
И. Н. КЛИЩ, Р. В. ВЕРБА
}

гВУз “Тернопольский государственный медицинский университет имени И. Я. Горбачевского МЗ Украины”

\title{
ИСПОЛЬЗОВАНИЕ СТВОЛОВЫХ КЛЕТОК ПУПОВИННОЙ КРОВИ ДЛЯ КОРРЕКЦИИ НАРУШЕ- НИЙ ЭНДОГЕННОЙ ИНТОКСИКАЦИИ У КРЫС С ОСТРЫМ РАСПРОСТРАНЕННЫМ ПЕРИТО- НИТОМ НА ФОНЕ МЕРКАЗОЛИ.-ИНДУЦИРОВАННОГО ГИПОТИРЕОЗА
}

\begin{abstract}
Цель работы: изучить влияние мезенхимальных стволовых клеток на показатели эндогенной интоксикации у крыс с острым распространенным перитонитом на фоне экспериментального гипотиреоза.

Материалы и методы. В работе использовали белых крыс линии Вистар. Гипотиреоз моделировали введением мерказолила в дозе 25 мг / кг в течение 21 суток. Острый распространенный перитонит моделировали введением 0,5 мл 10 \% профильтрованной каловой суспензии в брюшную полость исследуемых животных. Стволовые клетки получали из пуповинной крови беременных самок на 21-24 сутки беременности. Оценку жизнеспособности полученных клеток осуществляли с использованием теста на включение суправитального красителя методом окрашивания 0,1 \% раствором трипанового синего. Суспензию полученных мононуклеаров вводили внутрибрюшинно в дозе 0,5 мл (количество клеток в введенной дозе $-0,9-1,0 \times 10^{8}$ ) сразу после моделирования острого распространенного перитонита. Проведено определение молекул средней массы, эритроцитарного и лейкоцитарного индексов интоксикации, активности катепсина D.

Результаты исследований и их обсуждение. Проведенными исследованиями установлено, что наличие гипотиреоза у экспериментальных животных, которым моделировали острый распространенный каловый перитонит, сопровождалось более выраженным, чем в эутиреоидных крыс, ростом показателей эндотоксикоза - среднемолекулярных пептидов, эритроцитарного и лейкоцитарного индексов интоксикации и более медленной динамикой их нормализации. Наблюдались фазовые изменения активности катепсина D. Применение стволовых клеток пуповинной крови сопровождается существенным уменьшением эндогенной интоксикации у животных с экспериментальным распространенным перитонитом на фоне мерказолилиндуцированного гипотиреоза.

Выводы. Дефицит йодсодержащих гормонов щитовидной железы сопровождается достоверным ростом показателей, характеризующих синдром эндогенной интоксикации по сравнению с еутиреоидными животными. Это может быть одной из причин развития полиорганной недостаточности при этих условиях. Применение стволовых клеток пуповинной крови сопровождается существенным уменьшением эндогенной интоксикации у животных с экспериментальным распространенным перитонитом на фоне мерказолил-индуцированного гипотиреоза.
\end{abstract}

Ключевые слова: распространенный перитонит; гипотиреоз; эндогенная интоксикация; коррекция; стволовые клетки; пуповинная кровь. 